JARES, Vol. 2 No. 1 March, 2017; p-ISSN: 2502-826X; e-ISSN: 2503-1163

Copyrights@ Balitar Islamic University, Blitar, Indonesia; Http://jares.unisbablitar.ejournal.web.id

Citation: Azimah, Anis . 2017. The Use of English Movies on Improving Students' Interest in Learning English at SMP Negeri 2 Ngunut. JARES, (2017), 2(1): 34-41

\title{
THE USE OF ENGLISH MOVIES ON IMPROVING STUDENTS' INTEREST IN LEARNING ENGLISH AT SMP NEGERI 2 NGUNUT
}

\author{
Anis Azimah \\ English Education Department, IAIN Tulungagung \\ anisazimah@outlook.com
}

\begin{abstract}
In language learning, technology is an attractive media to the students, along with the development of the information technology, teacher should build up the learning process to be more interesting. Learning language successfully depends on many factors. One of the factors is interest of the learners themselves. Interest is an attitude favorably disposing and motivating one toward some objects, situations or idea. It relates to the activity which makes the learners to be involved in language learning process. In teaching English, teacher should conduct some techniques communicatively to build students' interest in learning process. Films are closed related to students' life. Younger likes watching movies or films. So, teacher can use films as the media in teaching English. It also can attract students to have high participation during learning process. Watching English movies can also be used as a technique to improve students' interest. It is not only improving students' interest, but also improving their achievement.
\end{abstract}

Keywords : English Movie, Learning Interest.

Received: 6 February, 2017; Accepter: 15 March, 2017

\section{INTRODUCTION}

We cannot deny the fact that language is very important in our life. As human being we can not live alone in this world, we need to communicate with others to fulfill our needs. In communication with others, we must use something to express our idea in order to be understood by others people. In this case, language is the most essential and effective means of communication.

There is no exactly the same language in the world. It seems that every nation has its own language. That is way sometimes we get difficulty in communicating with people from another country who have different language. In having communication with people who have different language, one must learn others language.

Leonard Bloomfield (1933:57) says that English plays an important role in every aspect of human life such as communication, economic, education, science, 
JARES, Vol. 2 No. 1 March, 2017; p-ISSN: 2502-826X; e-ISSN: 2503-1163

Copyrights@ Balitar Islamic University, Blitar, Indonesia; Http://jares.unisbablitar.ejournal.web.id

Citation: Azimah, Anis . 2017. The Use of English Movies on Improving Students' Interest in Learning English at SMP Negeri 2 Ngunut. JARES, (2017), 2(1): 34-41

technology, and so on. And the fact says that English is most frequently used in international relationship.

Due to the important of English, Indonesian government has determined English as the first foreign language in our country. One of the efforts of our government is that English is taught to Indonesian students since they are in the elementary school.

Based on the pre-observation conducted in the eighth grade students of SMP N 2 Ngunut Tulungagung, it was noticed that the students still get difficulties in understanding English and lack of interest. The fact is that the students often made mistakes in doing the assignments given by the teacher. During the pre-observation, it was also noticed that there were some problems dealing with teaching and learning process as follows:

1. The learning process was textbook-oriented. The teacher mostly based her teaching on a certain worksheet (LembarKegiatanSiswa). There were no various sources used and various activities done during the lesson. The students only moved from task to task stated in the book by answering questions based on a certain reading text in that book (LKS).

2. The students were not actively engaged in the learning activities. There were little opportunities for unconfident students to get involved in the lesson. Only the active students can learn better.

From the interview with the teacher, it was known that the students are not enthusiastic and interested in learning English. She never use the other material from another sources like internet, magazines, newspapers, movie etc. She said that only few students had great willingness to answer comprehension questions voluntarily. Most of them were passive; they answered the questions only if the teacher point out them to answer. In addition, the students said that they felt bored with the lesson.

Those cases faced by the eighth grade students in SMP $\mathrm{N} 2$ Ngunut Tulungagung might considerably occur because the method used by the teacher is not motivating for the students. The Students are bored with the habitual learning activities having described above. Therefore, the teacher has to be able to use her creativity to establish inviting, enjoyable and motivating classroom environment. One of the ways is by applying various teaching materials into learning activities. One of the appropriate materials is from movie.

In order to improve students' reading comprehension, our government has set an approach that is suitable to improve students' interest of reading what the so-called Genre-based Approach. This approach provides students with many kinds of texts based on genre, such as narrative, description, procedure, spoof, news item, analytical exposition, etc. The aim of this approach is to introduce text's genre in order to enable the students to identify its social purpose and its generic structure, and also to improve students' comprehension in understanding text. Most of the students feel that 
reading activity is burdensome and boring. Some of them delay the reading activity so long. They feel bored and less of motivation.

Learning language successfully depends on many factors. On of the factors is interest of the learners themselves. Interest is an attitude favorably disposing and motivating one toward some objects, situations or idea. It relates to the activity which makes the learners to be involved in language learning process.

Everybody knows that understanding English is not as easy as understanding Indonesian. Students are faced with differences in sounds, words, sentences, grouping thing, persons, action, and arrangements. These differences will cause a problems and difficulties when they are learning language. And when students feel that English is difficult, psychologically they are not interested again in learning. The low interest in learning process causes their attention to the taught material become low. Student's low interest can be caused by: (1) the teacher is not creative in using media as aids of teaching. (2) the teachers teach grammar rather than using language. (3) the teacher only gives a little time to practice their skills.

Nowadays, people can meet their needs easily due to the development of technology. Younger likes watching movies or films. So, teacher can use films as the media in teaching English. It also can attract students to have high participation during learning process.

\section{RESEARCH METHOD}

This research uses descriptive qualitative approach. The qualitative descriptive method is used to collect data directly through observation, interviews, and taking the results of learning in the form of tests. The data obtained is described in the form of words to be a report. This research will be conducted in the implementation of PTK or Classroom Action Research based on the problems that have been described in the background.

Research subjects in this study are the students of class VIII SMP Negeri 2 Ngunut with the number of students as many as 35 students. Methods of data collection in this study are interview method, observation, field notes, and documentation. The sampling method is the same as sampling in a quasi experiment. According to Cresswell (2010: 232) in quasi experiments using non-random samples, researchers usually use naturally formed groups (such as a class, organization or family) or volunteers.

1. Interview

Interviews needed in this study to determine the state of the subject of research such as the state of students in class VIII SMP Negeri 2 Ngunut, the value of students before applied learning, and data about class activeness information on the subject of research.

2. Observation 
Observation is one of the instruments used in collecting the data. The researcher observes the application of the lesson plans, students' activities in teaching and learning process.

3. Field Notes

Field notes are used to record things or findings obtained in the field that is not summarized in the observation.

4. Documentation

This documentation is used to document activities in the form of photo or video of learning activities when applying the mind mapping method.

\section{RESULT AND DISCUSSION}

In the beginning of the research, the writer conducted pre observation toward the English teaching and learning process to know the pre-condition before the classroom action research was done. She found that the students had not been active in the teaching and learning process and they felt bored when they learn English. So, the students' interest was still low. It was supported by the student when the researcher interviewed her.

$\begin{array}{ll}\text { Researcher } & \text { : Apakah sampean suka pelajaran Bahasa Inggris? } \\ \text { Student } & \text { : Biasa saja, kadang malah males. } \\ \text { Researcher } & \text { : Kenapa malas dengan pelajaran Bahasa Inggris? } \\ \text { Student } & : \text { Karena bosan, hanya mengerjakan LKS, buku paket, } \\ & \text { membaca, mengerjakan, PR. Selalu berulang terus seperti itu } \\ \text { Researcher } & : \text { Apakah guru bahasa inggris belum pernah mengajar } \\ & \text { menggunakan media film? } \\ \text { Teacher } & \text { : belum pernah. }\end{array}$

There were some cases that caused the problems above, namely the text was not interesting and the media of instruction of delivering material was not suitable and interesting.

Considering those causes and based on the pre observation, the writer identified that the students' interest should be improved by implementing a teaching learning process which can overcome the problem. Therefore, the writer designed instructional materials, in this case the writer using movie.

The results based on observations made in the classroom during the learning process took place by applying the movie. In the learning process of teachers at the beginning of the learning explain the first step is to explain the purpose of learning, the material being taught, and the use of movie as media. The learning steps undertaken by the teacher consists of the beginning, core, and closing activities.

1. Initial activity

In the initial activity, the teacher opened the opening by praying, checking the readiness of the students in the lesson, explaining the purpose of learning, 
explaining what the purpose of the material will be taught, building student knowledge by asking about the material to be taught, and explaining the use of learning media that will be used is movie .

Beginning the lesson, the students looked very fresh because it was the first lesson of that day. The class was not noisy, but the surrounding was very noisy. The researcher tried to create a good atmosphere by telling the students that the day's activities would be watching movie as media to learn narrative text. The students seemed enthusiastic. In this stage, the researcher showed some picture of Rapunzel on the slide and gave orally questions about it.

1. Have you ever watched Rapunzel's movie before?

2. Do you like movie?

3. Do you know the story of Rapunzel?

The teacher introduced the movie and it's contain. The teacher explain that the material of narrative text adopted from movie.

2. Core learning The core activity is done by applying the movie as media. Before applying the movie, the teacher previously explained the subject matter of need and did the questioning. In this activity, students respond to the treatment of teachers by raising their hands and answering questions from the teacher. The students began to give a good response to the movie which is given. They could enjoy the movie. Classroom situation began cheer up, when the movie was begun. It could be said that the teacher could manage the time well. The students were critics. They had initiative to add the explnation and respond their friends' answers. The teacher asked the students to rewrite the story of Rapunzel using their own words. Although they make some mistake and open their dictionary, they are very interest and anthusias to do it. In this stage, there are still some students who seem not yet active in the learning process.

3. Closing

Closing is the last activity done by the teacher during the lesson. Closing is done to reflect all learning activities that have been done. At this stage, the teacher reviews the material with the students by way of question and answer, assigning tasks, and giving a closing greeting to meet at next week's meeting. The teacher asked to the students about their teaching and learning process using movie as media. And they directly answer together that they very interesting with the material and teaching learning process.

In the application, teacher can use English movies to teach four skills. They include listening, speaking, and also writing skill. By using English movie, teacher can also teach grammar and introduce new vocabulary for students.

\section{a. Listening Skill}

watching movie can produce audio elements, teacher can use English movie as the media to teach Junior high school students listening skill. Teacher plays the 
JARES, Vol. 2 No. 1 March, 2017; p-ISSN: 2502-826X; e-ISSN: 2503-1163

Copyrights@ Balitar Islamic University, Blitar, Indonesia; Http://jares.unisbablitar.ejournal.web.id

Citation: Azimah, Anis . 2017. The Use of English Movies on Improving Students' Interest in Learning English at SMP Negeri 2 Ngunut. JARES, (2017), 2(1): 34-41

movie without showing its Indonesian subtitle and outomatically the student can improve their listening skill. Listening using native speaker is hard for understanding, but the students very interest when the teacher plays the movie. This statement was also supported by Yulidar Dwi Pramushinta as a student of VIIIA.

The researcher : Apakah kamu suka dengan pelajaran narrative menggunakan film sebagai media pembelajaran? Kenapa?

Yulidar $\quad$ : Iya, suka sekali. Karena dengan menggunakan film saya merasa itu hal baru dan sangat menarik. Bisa lebih faham dengan ceritanya karena didukung oleh adegan film.

\section{b. Speaking Skill}

In addition to listening skill, teacher can use English movies to teach Speaking skill. After the student watch the movie, the teacher ask some question orally.

\section{c. Writing skill}

By using English movies, teacher can also teach writing skill. In writing skill, the teacher ask to the student to rewrite the story using their own words.

\section{d. Grammar}

It is obviously seen that by using English movies, teacher can teach listening, speaking and writing skill. Nevertheless, in spite of those three skills, teacher can also use English movies to teach grammar. Related to the material, its about narrative text, the teacher explain about simple past tense.

\section{e. New vocabulary}

Implementing English movies in teaching English as a Foreign Language to Junior high school students can also improve students' vocabulary. Students not only get fun learning environment, but they also get new vocabulary from the movie they watch. Teacher can conduct teaching vocabulary by playing English movies without showing the Indonesian subtitle. Teacher can also ask students to write strange words in the movie for them. After watching the movie, teacher can ask some students to share what new words they learned from the movie. Following the activity, and as the individual task, teacher asks students to find the Indonesian meaning of the new words.

English becomes an important language. It has spread around the world so extensively, making it a truly international language. Thus, learning English is a requisite for anyone to master it and to use it for communication with people around the world. 
Learning English as the first foreign language is not an easy work. Learners have to learn a language that has differences with their mother tongue, like the vocabulary, spelling, and word formation and so on.

For some teachers, it might be not easy to teach English. They will find that students are not interested again in learning English, although it is a new subject for them. Their low interest will influence students' achievement and also learning objectives can not be reached

Learning language successfully depends on many factors. One of the factors is interest of the learners themselves. Munn (1986:181) says interest is an attitude favorably disposing and motivating one toward some objects, situation or idea. It relates to the activity, which makes the learners to be involved in language learning process. It gives the reason of the learners to the activity of the language learning process.

In teaching English, teacher should conduct some techniques communicatively to build students' interest in learning process. Films are closed related to students' life. It provides some opportunities for students to learn English. Film, related to students' interest, seems to be an effective technique in teaching English because it will reduce students' anxiety to express them selves. Furthermore, when the movie or film played in the classroom, the students will get an interesting classroom condition.

Kemp (1963: 3) states as follows,"When such audio visual material, as photographs, slides, filmstrips, overhead transparencies, and motion pictures are carefully prepared and properly used, they can:

1. Increase understanding of a topic.

2. Add interest to a subject.

3. Lengthen the retention time of information.

4. Teach skill effectively.

5. Contribute to a desirable attitude

6. Stimulate people to act.

7. Offer experiences not easily obtained in other ways"

Therefore, it can be seen that interest is very important in education because of its function as a sources of actions. If interest is accompanied by the direct and guided one, a person will be more active and finally can achieve what he expects.

Based on the theory underlying, it seems that English films can improve student's learning interest. Having high interest on English will improve students' achievement. 


\section{CONCLUSION AND SUGGESTION Conclusion}

Based on the discussion above, it can be concluded that movie can be used as teaching media. Watching English movies can also be used as a technique to improve students' interest. It is not only improving students' interest, but also improving their achievement.

\section{Suggestion}

Teaching English using films is an effective technique in improving students' interest. Therefore, the writer would like to propose suggestion as follows:

1. Teacher should be more creative in teaching English in order to improve students' interest in learning English. Choosing of the teaching technique should be appropriate with the level of the students.

2. It is necessary to apply different technique to avoid the monotonous technique. So that, students will not feel bored.

3. Teacher should give students time to use their language skills. Because the objective of teaching English ins to make students to be able to communicate both written or oral with other people.

\section{References}

Allen, R. C., and D. Geomer. 1985. Film History: Theory and Practice. New York: McGrow-Hill

Bloomfield, Leonard.1933. Language. New York: Holt, Rinehart and Winston.

Bordwell, David, Kristin Thompson. (1996). Film Art: An Introduction. New York: The McGraw-Hill Companies, Inc.

Creswell, J. W. (2010). Research design: pendekatan kualitatif, kuantitatif, dan mixed. Yogjakarta: PT Pustaka Pelajar.

H.C. Witherington, Lee J. Cronbach dan Bapemsi, Teknik -Teknik Belajar Dan Mengajar, Jemmars, 1982

Nasution (1992), Metode Penelitian Naturalistik Kualitatif, Penerbit Tarsito, Bandung.

Purwanto Ngalim. 1990. Belajar Berhubungan Dengan Perubahan Tingkah Laku. Jakarta: PT Rineka Cipta.

Webster (1983:105) dalam kutipan Arsyad (2002) Media Pembelajaran : Jakarta PT Raja Garfindo Perasada.

Wittich and Schuller (1979), Audio Visual Materials Third Edition, USA: Harper and Brothers. 